\title{
Article \\ A Retrospective Analysis of Randomized Controlled Trials on Traumatic Brain Injury: Evaluation of CONSORT Item Adherence
}

\author{
Meltem Elcivan ${ }^{1}$, Ana Kowark ${ }^{2}$, Mark Coburn ${ }^{3}{ }^{-}$, Hussam Aldin Hamou ${ }^{1}$, Benedikt Kremer ${ }^{1}$, Hans Clusmann ${ }^{1}$ \\ and Anke Höllig 1,*(D) \\ 1 Department of Neurosurgery, University Hospital RWTH Aachen, Pauwelsstr. 30, D-52074 Aachen, Germany; \\ meltem.elcivan@rwth-aachen.de (M.E.); hhamou@ukaachen.de (H.A.H.); bkremer@ukaachen.de (B.K.); \\ hclusmann@ukaachen.de (H.C.) \\ 2 Department of Anaesthesiology, University Hospital RWTH Aachen, Pauwelsstr. 30, \\ D-52074 Aachen, Germany; akowark@ukaachen.de \\ 3 Department of Anaesthesiology and Intensive Care Medicine, University Hospital Bonn, \\ Venusberg-Campus 1, D-53127 Bonn, Germany; mark.coburn@ukbonn.de \\ * Correspondence: ahoellig@ukaachen.de; Tel.: +49-241-8088481
}

check for

updates

Citation: Elcivan, M.; Kowark, A.;

Coburn, M.; Hamou, H.A.; Kremer, B.;

Clusmann, H.; Höllig, A. A

Retrospective Analysis of

Randomized Controlled Trials on

Traumatic Brain Injury: Evaluation of CONSORT Item Adherence. Brain Sci. 2021, 11, 1504. https://doi.org/

10.3390/brainsci11111504

Academic Editor: Nada Andelic

Received: 6 September 2021

Accepted: 3 November 2021

Published: 13 November 2021

Publisher's Note: MDPI stays neutral with regard to jurisdictional claims in published maps and institutional affiliations.

\section{Copyright: (c) 2021 by the authors.} Licensee MDPI, Basel, Switzerland. This article is an open access article distributed under the terms and conditions of the Creative Commons Attribution (CC BY) license (https:// creativecommons.org/licenses/by/ $4.0 /)$.

\begin{abstract}
Traumatic brain injury (TBI) contributes to death and disability, resulting in an enormous individual and socio-economic challenges. Despite huge efforts, there are still controversies on treatment strategies and early outcome estimation. We evaluate current randomized controlled trials (RCTs) on TBI according to their fulfillment of the CONSORT (Consolidated Statement of Reporting Trials) statement's criteria as a marker of transparency and the quality of study planning and realization. A PubMed search for RCTs on TBI (January 2014-December 2019) was carried out. After screening of the abstracts $(n=1.926)$, the suitable full text manuscripts $(n=72)$ were assessed for the fulfillment of the CONSORT criteria. The mean ratio of consort statement fulfillment was $59 \%( \pm 13 \%), 31 \%$ of the included studies $(n=22)$ complied with less than $50 \%$ of the CONSORT criteria. Citation frequency was moderately related to ratio of CONSORT item fulfillment $(r=0.4877$; $p<0.0001)$ and citation frequency per year $(r=0.5249 ; p<0.0001)$. The ratio of CONSORT criteria fulfillment was associated with the impact factor of the publishing journal $(r=0.6428 ; p<0.0001)$. Essential data for study interpretation, such as sample size determination (item 7a), participant flow (item 13a) as well as losses and exclusions (item 13b), were only reported in 53\%, 60\% and 63\%, respectively. Reporting and methodological aspects in RCTs on TBI still may be improved. Thus, the interpretation of study results may be hampered due to methodological weaknesses.
\end{abstract}

Keywords: TBI; randomized controlled trial; CONSORT criteria; methodology

\section{Introduction}

Traumatic brain injury (TBI) worldwide is one of the leading causes for disability. Data for 2016 reveal an age-standardized incidence of 369 (331-412) per 100,000 population for TBI globally [1]. Further, survivors suffer from disabilities [2] and have an increased risk for the occurrence of stroke, psychiatric diseases, dementia and other neurodegenerative disorders [3-5].

Randomized controlled trials (RCTs) are crucial for clinical decision-making and the creation of clinical guidelines. A transparent, complete and unbiased reporting on methods, conduct and results is essential to allowing a well-considered evaluation of the data. To increase the transparency of reporting, the Standardized Reporting of Trials (SORT) statement was first published in 1994 [3]. The statement was updated and merged with the Asilomar Guideline (by the Asilomar Working Group on Recommendations for Reporting of Clinical Trials in the Biomedical Literature; [4]) in 1996 (as the Consolidated Standards of Reporting Trials (CONSORT) Statement). Further refreshment took place in 2010 [3,5,6]. 
It is all the more important that the methodological and reporting issues are taken into account as TBI-specific aspects (as the heterogeneity of TBI [7,8]) may also influence the conduct of studies.

In 2015, Lu and colleagues provided an overview of CONSORT criteria compliance of RCTs on TBI (from 1976 to September 2013) and showed that several methodological aspects have improved over time [9]. However, the compliance of some fundamental items remained low and most studies seemed to be underpowered [9].

In order to update the available data, we analyzed the RCTs on TBI (January 2014December 2019) with respect to their CONSORT criteria adherence and complemented the findings with a correlation of the citation frequencies and the impact factors of the publishing journals.

\section{Materials and Methods}

We performed a retrospective analysis of RCTs on TBI (published from January 2014 to December 2019) and reported the data according to the STROBE statement [10]. A PubMed search was carried out using the following search terms: [(traumatic brain injury) OR TBI OR (brain trauma) OR (head injury)] AND [(randomized controlled) OR randomized OR RCT]. Two authors (ME and AH) screened all abstracts for inclusion (applying the following inclusion criteria: randomized controlled clinical trial on patients with TBI within the acute treatment period). A Flowchart displays the excluded studies and the corresponding reasons for exclusion (see Flowchart; Figure 1). The included studies were evaluated according to their CONSORT criteria adherence by the first author (ME) [6]. A datasheet with precise descriptions of each item a priori was established in order to minimize subjective interpretation. Discrepancies regarding the study allocation were discussed with a second author (AH). Furthermore, $10 \%$ of all included RCTs were randomly double-checked by a second author (AH). Additionally, in the case of uncertainties about the assignment according to the CONSORT criteria, the specific item was discussed with a second author (AH). The journals' websites were checked for supplemental material, which was included if available. Every item was classified as "fulfilled" (f), "not fulfilled" (nf) or "not applicable" (na). The classification "na" was used for items which are not mandatory, for example, item $7 \mathrm{~b}$, "When applicable, explanation of any interim analyses and stopping guidelines".

According to the year the manuscript was published, the citation frequency and the impact factor of the journal were assessed using the Web of Science (Clarivate Analytics). The citation frequency per year was calculated to eliminate the bias derived from being available for a longer period of time. Some studies (specification see results section) were not available on the Web of Science. These studies were analyzed according to the CONSORT criteria adherence but correlation analyses with impact factor and citation frequency were not possible.

\section{Statistical Methods}

For each item of the CONSORT criteria, the percentage of adherence was calculated. Additionally, summary statistics were assessed and graphically presented. Impact factor, citation frequency and citation frequency per year were correlated with CONSORT criteria fulfillment. As non-linear relationships were observed, we calculated the Spearman's rank-order correlation (computing the coefficient $r$ ) and reported the corresponding $p$-value. For better visualization (due to non-linear relationship), logarithmic axes were used. Therefore, the graphical representation citation frequencies with a value of zero were set to 0.001. All our statistical analyses were performed using GraphPad Prism 9.1 (GraphPad Prism Software Inc., La Jolla, CA, USA). A p-value of 0.05 was regarded statistically significant. 


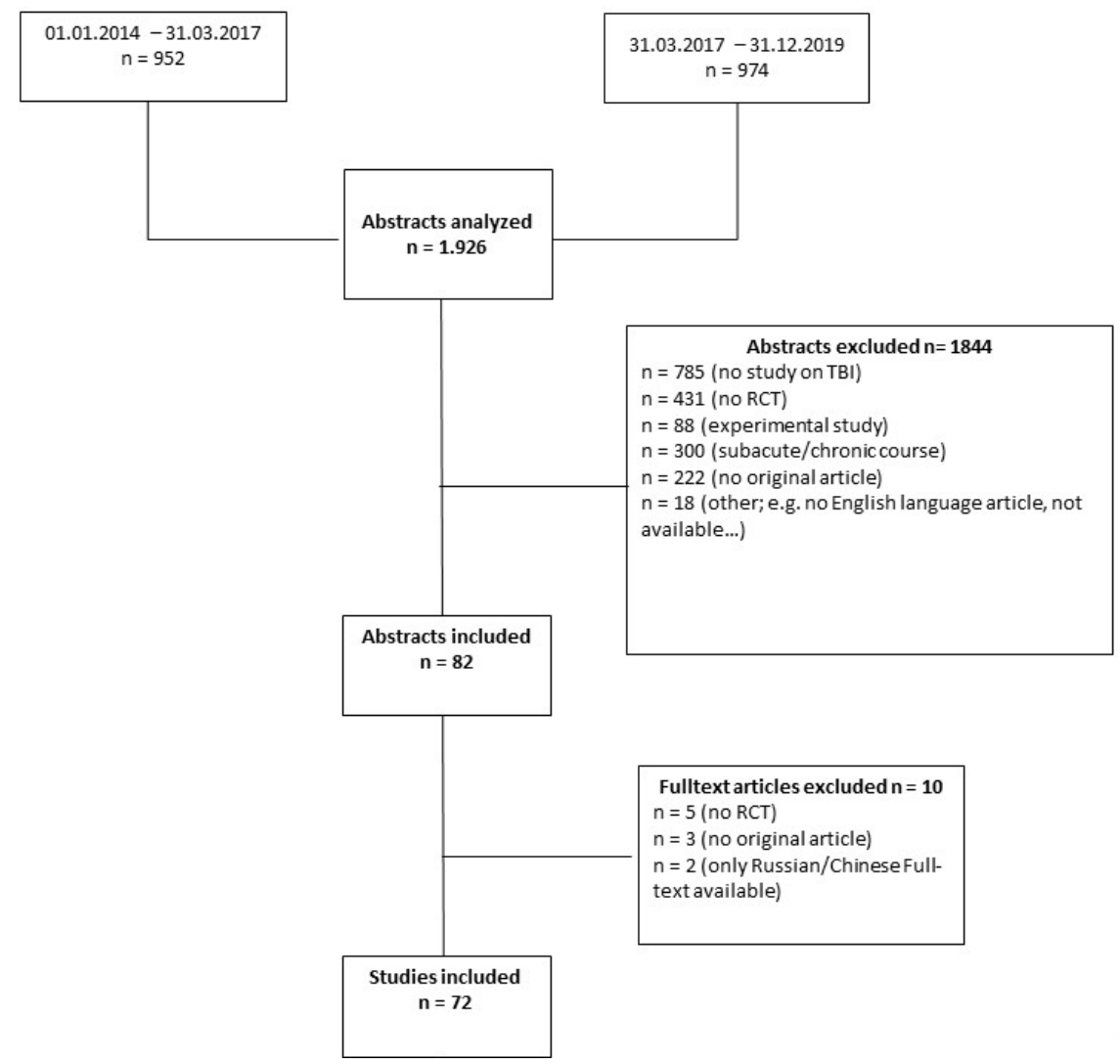

Figure 1. Flowchart of the studies included.

\section{Results}

The PubMed search (January 2014-December 2019) resulted in 1926 abstracts (see Flowchart, Figure 1). A total of 1844 abstracts were excluded due to the following reasons: no study on TBI $(n=785)$, no RCT $(n=431)$, laboratory study $(n=88)$, delayed intervention (e.g., study on rehabilitation techniques; $n=300)$, no original article $(n=222)$, other reasons ( $n=18$ ).During the further analysis of the 82 studies left, five studies had to be excluded, as the full-text revealed that the studies did not meet the criteria of RCTs; two more articles had to be excluded as the full-texts were only available in Russian/Chinese; three articles were identified as review articles. Therefore, a total of 72 articles [11-82] were finally analyzed (see Flowchart, Figure 1). For four studies, no impact factor of the publishing journal was listed [16,38-40,76,77]. Further, 11 articles were not available through the Web of Science database search at all $[12,15,33,41,51,55,56,66,74,79,81]$. Details on the studies, including specific interventions, number of patients and outcome measures, are attached as a Supplemental Data File.

A mean ratio of fulfillment of $59 \%( \pm 13 \%)$ was observed among the entire $37 \mathrm{CON}$ SORT items. A total of 21 studies ( $29 \%$ ) complied with less than $50 \%$ of the items (minimum: $35 \%$ ). The highest fulfillment rate was observed with $87 \%$. Of note, there are a few items, which do not necessarily have to be fulfilled (e.g., item 3b "Changes to trial design" or item $11 \mathrm{~b}$ "Similarity of interventions: If relevant, description of the similarity of interventions"). The distribution of the CONSORT criteria fulfillment is shown in Figure 2. 

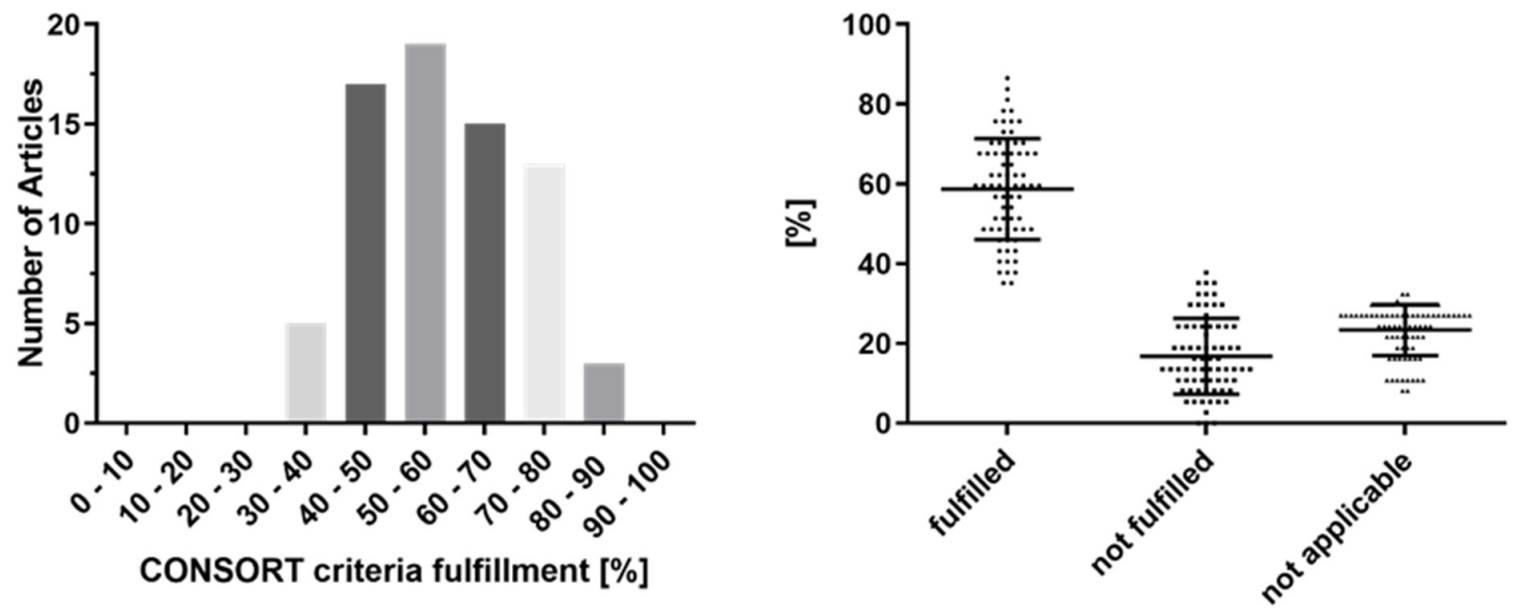

Figure 2. CONSORT criteria fulfillment: (left) numbers of articles according to their CONSORT criteria fulfillment; (right) distribution of CONSORT criteria fulfillment.

The fulfillment of some items is essential in order to allow an appropriate assessment of the relevance of the results. Fundamental items, such as the determination of sample size (item 7a), participant flow (item 13a) and the indication of losses and exclusions (item $13 \mathrm{~b})$, were only fulfilled in about $60 \%$ of the studies (53\%, 60\% and $63 \%)$. The specific fulfillment ratios for each item are presented in Table 1.

Table 1. Specific fulfillment ratios.

\begin{tabular}{|c|c|c|c|}
\hline Item & \multicolumn{2}{|c|}{ Item Description } & $\begin{array}{l}\text { Items Fulfilled } \\
n /(\%)\end{array}$ \\
\hline & $1 \mathrm{a}$ & Identification as a randomised trial in the title. & $n=42 ; 58.3 \%$ \\
\hline & $1 b$ & $\begin{array}{l}\text { Structured summary of trial design, methods, results, } \\
\text { and conclusions. }\end{array}$ & $n=70 ; 98.6 \%$ \\
\hline \multicolumn{4}{|l|}{ Introduction } \\
\hline \multirow{2}{*}{ Background and objectives } & $2 \mathrm{a}$ & Scientific background and explanation of rationale. & $n=72 ; 100 \%$ \\
\hline & $2 b$ & Specific objectives or hypotheses. & $n=68 ; 94.4 \%$ \\
\hline \multicolumn{4}{|l|}{ Methods } \\
\hline \multirow{2}{*}{ Trial design } & 3a & $\begin{array}{l}\text { Description of trial design (such as parallel, factorial) including } \\
\text { allocation ratio. }\end{array}$ & $n=70 ; 97.2 \%$ \\
\hline & $3 b$ & $\begin{array}{l}\text { Important changes to methods after trial commencement (such as } \\
\text { eligibility criteria), with reasons. }\end{array}$ & $n=3 ; 4.2 \%$ \\
\hline \multirow{2}{*}{ Participants } & $4 \mathrm{a}$ & Eligibility criteria for participants. & $n=72 ; 100 \%$ \\
\hline & $4 b$ & Settings and locations where the data were collected. & $n=67 ; 93.1 \%$ \\
\hline Interventions & 5 & $\begin{array}{l}\text { The interventions for each group with sufficient details to } \\
\text { allow replication, including how and when they were } \\
\text { actually administered. }\end{array}$ & $n=71 ; 98.6 \%$ \\
\hline \multirow{2}{*}{ Outcomes } & $6 a$ & $\begin{array}{l}\text { Completely defined pre-specified primary and secondary outcome } \\
\text { measures, including how and when they were assessed. }\end{array}$ & $n=70 ; 97.2 \%$ \\
\hline & $6 b$ & $\begin{array}{l}\text { Any changes to trial outcomes after the trial commenced, } \\
\text { with reasons. }\end{array}$ & $n=2 ; 2.8 \%$ \\
\hline \multirow[b]{2}{*}{ Sample size } & $7 \mathrm{a}$ & How sample size was determined. & $n=38 ; 52.8 \%$ \\
\hline & $7 \mathrm{~b}$ & $\begin{array}{l}\text { When applicable, explanation of any interim analyses and } \\
\text { stopping guidelines. }\end{array}$ & $n=8 ; 11.1 \%$ \\
\hline
\end{tabular}


Table 1. Cont.

\begin{tabular}{|c|c|c|c|}
\hline Item & \multicolumn{2}{|c|}{ Item Description } & $\begin{array}{l}\text { Items Fulfilled } \\
n /(\%)\end{array}$ \\
\hline \multicolumn{4}{|l|}{ Randomisation: } \\
\hline \multirow[b]{2}{*}{ Sequence generation } & $8 a$ & Method used to generate the random allocation sequence. & $n=59 ; 81.9 \%$ \\
\hline & $8 b$ & $\begin{array}{l}\text { Type of randomisation; details of any restriction (such as blocking } \\
\text { and block size). }\end{array}$ & $n=35 ; 48.6 \%$ \\
\hline $\begin{array}{l}\text { Allocation concealment } \\
\text { mechanism }\end{array}$ & 9 & $\begin{array}{l}\text { Mechanism used to implement the random allocation sequence (such } \\
\text { as sequentially numbered containers), describing any steps taken to } \\
\text { conceal the sequence until interventions were assigned. }\end{array}$ & $n=30 ; 41.7 \%$ \\
\hline Implementation & 10 & $\begin{array}{l}\text { Who generated the random allocation sequence, who enrolled } \\
\text { participants, and who assigned participants to interventions. }\end{array}$ & $n=10 ; 13.9 \%$ \\
\hline \multirow[t]{2}{*}{ Blinding } & $11 \mathrm{a}$ & $\begin{array}{l}\text { If done, who was blinded after assignment to interventions (for } \\
\text { example, participants, care providers, those assessing outcomes) } \\
\text { and how. }\end{array}$ & $n=44 ; 61.1 \%$ \\
\hline & $11 b$ & If relevant, description of the similarity of interventions. & $n=3 ; 4.2 \%$ \\
\hline \multirow[t]{2}{*}{ Statistical methods } & $12 \mathrm{a}$ & $\begin{array}{l}\text { Statistical methods used to compare groups for primary and } \\
\text { secondary outcomes. }\end{array}$ & $n=71 ; 98.6 \%$ \\
\hline & $12 b$ & $\begin{array}{l}\text { Methods for additional analyses, such as subgroup analyses and } \\
\text { adjusted analyses. }\end{array}$ & $n=11 ; 15.3 \%$ \\
\hline \multicolumn{4}{|l|}{ Results } \\
\hline \multirow{2}{*}{$\begin{array}{l}\text { Participant flow (a diagram is } \\
\text { strongly recommended) }\end{array}$} & $13 a$ & $\begin{array}{l}\text { For each group, the numbers of participants who were randomly } \\
\text { assigned, received intended treatment, and were analysed for the } \\
\text { primary outcome. }\end{array}$ & $n=43 ; 59.7 \%$ \\
\hline & $13 b$ & $\begin{array}{l}\text { For each group, losses and exclusions after randomisation, together } \\
\text { with reasons. }\end{array}$ & $n=45 ; 62.5 \%$ \\
\hline \multirow{2}{*}{ Recruitment } & $14 a$ & Dates defining the periods of recruitment and follow-up. & $n=60 ; 83.3 \%$ \\
\hline & $14 \mathrm{~b}$ & Why the trial ended or was stopped. & $n=7 ; 9.7 \%$ \\
\hline \multirow[t]{2}{*}{ Baseline data } & 15 & $\begin{array}{l}\text { A table showing baseline demographic and clinical characteristics for } \\
\text { each group. }\end{array}$ & $n=68 ; 94.4 \%$ \\
\hline & 16 & $\begin{array}{l}\text { For each group, number of participants (denominator) included in } \\
\text { each analysis and whether the analysis was by original assigned } \\
\text { groups. }\end{array}$ & $n=61 ; 84.7 \%$ \\
\hline \multirow[t]{2}{*}{ Outcomes and estimation } & $17 \mathrm{a}$ & $\begin{array}{l}\text { For each primary and secondary outcome, results for each group, } \\
\text { and the estimated effect size and its precision (such as } 95 \% \\
\text { confidence interval). }\end{array}$ & $n=70 ; 97.2 \%$ \\
\hline & $17 \mathrm{~b}$ & $\begin{array}{l}\text { For binary outcomes, presentation of both absolute and relative effect } \\
\text { sizes is recommended. }\end{array}$ & $n=2 ; 2.8 \%$ \\
\hline Ancillary analyses & 18 & $\begin{array}{l}\text { Results of any other analyses performed, including subgroup } \\
\text { analyses and adjusted analyses, distinguishing pre-specified } \\
\text { from exploratory. }\end{array}$ & $n=16 ; 22.2 \%$ \\
\hline Harms & 19 & $\begin{array}{l}\text { All important harms or unintended effects in each group (for specific } \\
\text { guidance see CONSORT for harms). }\end{array}$ & $n=40 ; 55.6 \%$ \\
\hline \multicolumn{4}{|l|}{ Discussion } \\
\hline Limitations & 20 & $\begin{array}{l}\text { Trial limitations, addressing sources of potential bias, imprecision, } \\
\text { and, if relevant, multiplicity of analyses. }\end{array}$ & $n=57 ; 79.2 \%$ \\
\hline Generalisability & 21 & Generalisability (external validity, applicability) of the trial findings. & $n=14 ; 19.4 \%$ \\
\hline Interpretation & 22 & $\begin{array}{l}\text { Interpretation consistent with results, balancing benefits and harms, } \\
\text { and considering other relevant evidence. }\end{array}$ & $n=72 ; 100 \%$ \\
\hline
\end{tabular}


Table 1. Cont.

\begin{tabular}{|c|c|c|c|}
\hline Item & \multicolumn{2}{|c|}{ Item Description } & $\begin{array}{l}\text { Items Fulfilled } \\
n /(\%)\end{array}$ \\
\hline \multicolumn{4}{|c|}{ Randomisation: } \\
\hline \multicolumn{4}{|c|}{ Other information } \\
\hline Registration & 23 & Registration number and name of trial registry. & $n=40 ; 55.6 \%$ \\
\hline Protocol & 24 & Where the full trial protocol can be accessed, if available. & $n=12 ; 16.7 \%$ \\
\hline \multirow[t]{2}{*}{ Funding } & 25 & $\begin{array}{l}\text { Sources of funding and other support (such as supply of drugs), } \\
\text { role of funders. }\end{array}$ & $n=39 ; 54.2 \%$ \\
\hline & & mean & $58.7 \%$ \\
\hline
\end{tabular}

For six articles, no impact factor was available (although listed in the Web of Science), eleven articles were not listed at all. The mean impact factor of the articles available $(n=55)$ was 10.5 ( \pm 18.8 ; minimum: 0.269; maximum: 72.4). Citation frequency and citation frequency per year were correlated with the impact factor of the publishing journal $(r=0.5763$ and $r=0.6526$, both $p<0.0001)$. Both citation frequency and citation frequency per year, were moderately associated with CONSORT criteria fulfillment ratios $(r=0.4877$ and $r=0.5249$; both $p<0.0001$ ) (see Figure 3). Higher impact factors of the publishing journal (assessed at the time of publication) were related to higher ratios of CONSORT criteria fulfillment $(r=0.6428 ; p<0.0001)$ (see Figure 4$)$.
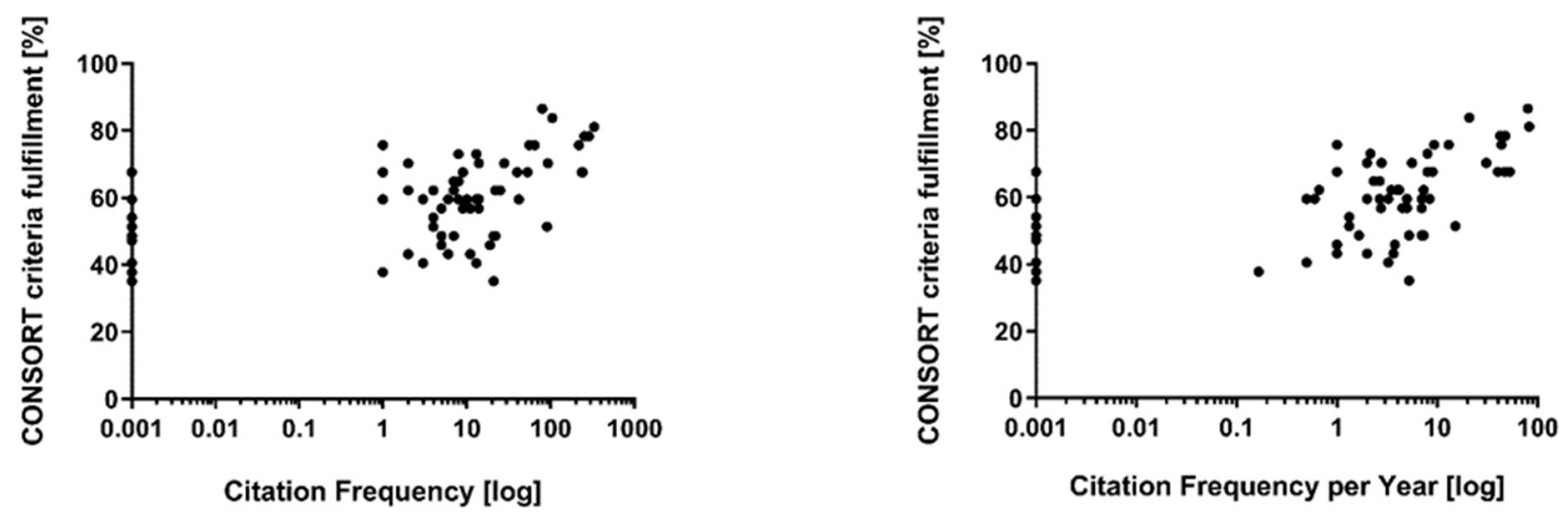

Figure 3. Correlation of citation frequency and CONSORT criteria fulfillment (left), citation frequency per year and CONSORT criteria fulfillment (right).

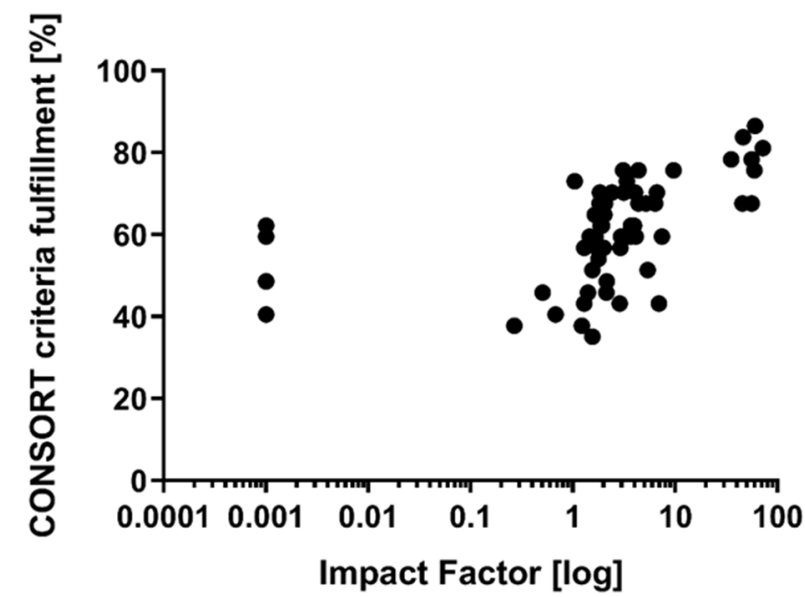

Figure 4. Correlation of impact factor of the publishing journal and CONSORT criteria fulfillment. 


\section{Discussion}

On average, the CONSORT criteria fulfillment ratios of studies on TBI are $59 \%$. Essential items for the understanding of the study concept and conduct (e.g., sample size determination and participant flow) show low adherence. The citation frequency and impact factor of the publishing journals are related with the ratio of CONSORT criteria fulfillment.

In 2015, Lu and colleagues published an analysis of RCTs on TBI with regards to CONSORT criteria adherence comparing the timespans from 1976 to 2001, from 2002 to 2010 and from 2011 to 2013 [9]. They observed an improvement of reporting quality over time, but also a low overall quality and particularly small sample sizes indicating underpowered studies. Unfortunately, an in-depth comparison of the data with our results is not possible as results were not provided for every CONSORT item (but only the methodological ones).

Our results are similar to a previously published analysis of RCTs on intracranial hemorrhage (ICH) [83], but here we report a higher mean fulfillment ratio (average: $59 \%$ vs. 51\%). This may be due to the different timeframe of inclusion (ICH study: January 2013March 2017). Matching the current data with two earlier studies evaluating CONSORT criteria fulfillment of neurosurgical RCTs $[84,85]$ the quality of reporting has improved slightly. In 2011, Kiehna and colleagues compared the CONSORT criteria adherence of RCTs published in four specific neurosurgical journals with those published in three leading general medicine journals (each published in 2006-2007) [84]. The adherence scores of the neurosurgical trials were far lower than those of the general medicine RCTs (mean score of 26.4 vs. 41 out of 44). Mansouri and colleagues analyzed neurosurgical RCTs from 2000 to 2014 using specific search terms [85]. Specific substantial items, such as sample size determination, were reported in only $20-34.2 \%$ (dependent on the sub-specialty of the study). On the one hand, only $50 \%$ of our analyzed studies reported information on sample size determination, which is an improvement compared to the results of Mansouri and colleagues. On the other hand, the description of sample size determination is an essential item for the interpretation of the study quality. Thus, a ratio of $50 \%$ is still disappointing.

Similar results were reported by Horton and colleagues, who particularly focused on the outcome measures in RCTs on TBI, and found heterogeneity in the use of outcomes and a variable quality of reporting [86]. The consequence of this lack of transparency is a possible misinterpretation of study results, which in turn may have consequences for clinical decision-making or the development of guidelines. Thus, adherence to the proper guidelines is not just about filling in the dots, but a necessity to reduce bias and to allow a complete and extensive understanding of the study. Further, it has to be emphasized that the mere fulfillment ratios do not take into account the importance of each item. Studies have to undergo an in-depth examination, as some items are essential for readers, reviewers and publishers in order to understand the intention and the concept of the study.

There is a vast amount of data documenting insufficient reporting in the health research literature regardless of the subspecialty and the ranking of the publishing journal [87-89]. Insufficient reporting is neither limited to neurosurgical topics nor is it a problem of RCTs. In fact, it is an important approach to increasing the sensitivity of the people involved (researchers, reviewer, publisher and readers) and make the problem public, as it is done by initiatives such as the EQUATOR network [90]. Awareness for data transparency and complete reporting (of positive and negative results) is needed [90,91]. Outcomes have to be defined properly, particularly when evidence exists that outcome measures are one problematic aspect of study conceptualization, which applies for TBI studies $[7,8,86,92]$.

In 2015, Lu and colleagues have already mentioned that several journals publishing studies on neurotrauma endorse the CONSORT guidelines [9]. Assessing high-impact journals, the endorsement of the CONSORT statement increased substantially over time [93]. Thus, our observed correlation of the impact factor of the publishing journal and CONSORT criteria fulfillment may be due to the growing interest in methodology and a consecutive increase in the journals' endorsements. 
Our results are subjected to several limitations: Some of the CONSORT items allow a certain scope of interpretation. Therefore, the judgement may be biased by subjective weighting (only $10 \%$ of the data were cross-checked). We reported fulfillment of the items but did not prioritize specific items according to their significance. Some of the items do not apply to all studies (e.g., item 3b "Important changes to methods after trial commencement (such as eligibility criteria), with reasons"). We have not subcategorized these items. Further, only one database (PubMed) was searched. Lastly, the non-pharmacological extension of the CONSORT statement has not been considered (as published in 2017 and not yet available for the studies published from 2014-2017) [94].

\section{Conclusions}

In conclusion, we present data on the CONSORT criteria of studies on TBI (published from January 2014 to December 2019). The CONSORT criteria adherence ratios are low $(59 \%)$. Bearing in mind that translational approaches in TBI research have largely failed, scientific approaches, methodology and reporting have to be reviewed. Adherence to certain quality standards should be requested by the journals. Importantly, these mandatory checklists should not only be a part of the submission process but also a transparent disclosure of the methodological approach and conduct of the study available for every reader. Further, the importance of methodological issues and the capability for critical analysis should be emphasized during the training of young academics.

Supplementary Materials: The following are available online at https://www.mdpi.com/article/10 $.3390 /$ brainsci11111504/s1, Table S1: overview of the studies analyzed.

Author Contributions: Design of study: A.H., A.K. and M.C.; acquisition of data: M.E., A.H. and H.A.H.; analysis and interpretation of data: M.E., A.H., B.K. and H.C.; conception or design of the work; or the acquisition, analysis, or interpretation of data for the work; first draft: M.E. and A.H.; revising of the manuscript: M.C., A.K., H.A.H., B.K. and H.C.; final approval: M.E., A.K., M.C., H.A.H., B.K., H.C. and A.H. All authors have read and agreed to the published version of the manuscript.

Funding: This project was funded by the "Hannelore Kohl Stiftung" (project number 2019012).

Data Availability Statement: Further data is available on request from the corresponding author.

Conflicts of Interest: No conflict of interest to declare.

\section{References}

1. James, S.L.; Theadom, A.; Ellenbogen, R.G.; Bannick, M.S.; Montjoy-Venning, W.; Lucchesi, L.R.; Abbasi, N.; Abdulkader, R.; Abraha, H.N.; Adsuar, J.C.; et al. Global, regional, and national burden of traumatic brain injury and spinal cord injury, 1990-2016: A systematic analysis for the Global Burden of Disease Study 2016. Lancet Neurol. 2018, 18, 56-87. [CrossRef]

2. Zaloshnja, E.; Miller, T.; Langlois, J.A.; Selassie, A.W. Prevalence of Long-Term Disability from Traumatic Brain Injury in the Civilian Population of the United States, 2005. J. Head Trauma Rehabil. 2008, 23, 394-400. [CrossRef] [PubMed]

3. A proposal for structured reporting of randomized controlled trials. The Standards of Reporting Trials Group. JAMA 1994, 272, 1926-1931. [CrossRef]

4. Working Group on Recommendation for Reporting of Clinical Trials in the Biomedical Literature Call for Comments on a Proposal to Improve Reporting of Clinical Trials in the Biomedical Literature. Ann. Intern. Med. 1994, 121, 894. [CrossRef]

5. Altman, D.G. Better reporting of randomised controlled trials: The CONSORT statement. BMJ 1996, 313, 570-571. [CrossRef]

6. Schulz, K.F.; Altman, D.G.; Moher, D.; for the CONSORT Group. CONSORT 2010 Statement: Updated Guidelines for Reporting Parallel Group Randomised Trials. PLoS Med. 2010, 7, e1000251. [CrossRef] [PubMed]

7. Menon, D.K.; Maas, A.I.R. Progress, failures and new approaches for TBI research. Nat. Rev. Neurol. 2015, 11, 71-72. [CrossRef]

8. Stein, D.G. Embracing failure: What the Phase III progesterone studies can teach about TBI clinical trials. Brain Inj. 2015, 29, 1259-1272. [CrossRef] [PubMed]

9. Lu, J.; Gary, K.W.; Copolillo, A.; Ward, J.; Niemeier, J.P.; Lapane, K.L. Randomized Controlled Trials in Adult Traumatic Brain Injury: A Review of Compliance to CONSORT Statement. Arch. Phys. Med. Rehabil. 2014, 96, 702-714. [CrossRef] [PubMed]

10. Von Elm, E.; Altman, D.G.; Egger, M.; Pocock, S.J.; Gøtzsche, P.C.; Vandenbroucke, J.P. The Strengthening the Reporting of Observational Studies in Epidemiology (STROBE) statement: Guidelines for reporting observational studies. J. Clin. Epidemiol. 2008, 61, 344-349. [CrossRef] 
11. Zafardoost, P.; Ghasemi, A.A.; Salehpour, F.; Piroti, C.; Ziaeii, E. Evaluation of the Effect of Glibenclamide in Patients with Diffuse Axonal Injury Due to Moderate to Severe Head Trauma. Trauma Mon. 2016, 21. [CrossRef] [PubMed]

12. Fan, M.-C.; Wang, Q.-L.; Fang, W.; Jiang, Y.-X.; Li, L.-D.; Sun, P.; Wang, Z.-H. Early Enteral Combined with Parenteral Nutrition Treatment for Severe Traumatic Brain Injury: Effects on Immune Function, Nutritional Status and Outcomes. Chin. Med. Sci. J. 2016, 31, 213-220. [CrossRef]

13. Rocca, A.; Pignat, J.-M.; Berney, L.; Jöhr, J.; Van De Ville, D.; Daniel, R.T.; Levivier, M.; Hirt, L.; Luft, A.R.; Grouzmann, E.; et al. Sympathetic activity and early mobilization in patients in intensive and intermediate care with severe brain injuries: A preliminary prospective randomized study. BMC Neurol. 2016, 16, 169. [CrossRef] [PubMed]

14. Hutchinson, P.J.; Kolias, A.; Timofeev, I.S.; Corteen, E.A.; Czosnyka, M.; Timothy, J.; Anderson, I.; Bulters, D.; Belli, A.; Eynon, C.A.; et al. Trial of Decompressive Craniectomy for Traumatic Intracranial Hypertension. N. Engl. J. Med. 2016, 375, 1119-1130. [CrossRef]

15. Bisri, T.; Utomo, B.A.; Fuadi, I. Exogenous lactate infusion improved neurocognitive function of patients with mild traumatic brain injury. Asian J. Neurosurg. 2016, 11, 151-159. [CrossRef] [PubMed]

16. Zamani, M.; Namdar, B.; Azizkhani, R.; Ahmadi, O.; Esmailian, M. Comparing the Antiemetic Effects of Ondansetron and Metoclopramide in Patients with Minor Head Trauma. Emergency 2015, 3, 137-140.

17. Lin, C.-M.; Lin, M.-C.; Huang, S.-J.; Chang, C.-K.; Chao, D.-P.; Lui, T.-N.; Ma, H.-I.; Liu, M.-Y.; Chung, W.-Y.; Shih, Y.-H.; et al. A Prospective Randomized Study of Brain Tissue Oxygen Pressure-Guided Management in Moderate and Severe Traumatic Brain Injury Patients. BioMed Res. Int. 2015, 2015, 1-8. [CrossRef] [PubMed]

18. Gregson, B.A.; Rowan, E.N.; Francis, R.; McNamee, P.; Boyers, D.; Mitchell, P.; McColl, E.; Chambers, I.R.; Unterberg, A.; Mendelow, A.D.; et al. Surgical Trial in Traumatic intraCerebral Haemorrhage (STITCH): A randomised controlled trial of Early Surgery compared with Initial Conservative Treatment. Health Technol. Assess. 2015, 19, 1-138. [CrossRef] [PubMed]

19. Aloizos, S.; Evodia, E.; Gourgiotis, S.; Isaia, E.-C.; Seretis, C.; Baltopoulos, G. Neuroprotective effects of erythropoietin in patients with severe closed brain injury. Turk. Neurosurg. 2015, 25. [CrossRef]

20. Andrews, P.J.; Sinclair, H.L.; Rodriguez, A.; Harris, B.A.; Battison, C.; Rhodes, J.K.; Murray, G.D. Hypothermia for Intracranial Hypertension after Traumatic Brain Injury. N. Engl. J. Med. 2015, 373, 2403-2412. [CrossRef] [PubMed]

21. Garner, A.A.; Mann, K.P.; Fearnside, M.; Poynter, E.; Gebski, V. The Head Injury Retrieval Trial (HIRT): A single-centre randomised controlled trial of physician prehospital management of severe blunt head injury compared with management by paramedics only. Emerg. Med. J. 2015, 32, 869-875. [CrossRef]

22. Mendelow, A.D.; Gregson, B.A.; Rowan, E.N.; Francis, R.; McColl, E.; McNamee, P.; Chambers, I.R.; Unterberg, A.; Boyers, D.; Mitchell, P.M.; et al. Early Surgery versus Initial Conservative Treatment in Patients with Traumatic Intracerebral Hemorrhage (STITCH[Trauma]): The First Randomized Trial. J. Neurotrauma 2015, 32, 1312-1323. [CrossRef] [PubMed]

23. Thomas, D.G.; Apps, J.N.; Hoffmann, R.G.; McCrea, M.; Hammeke, T. Benefits of Strict Rest After Acute Concussion: A Randomized Controlled Trial. Pediatrics 2015, 135, 213-223. [CrossRef] [PubMed]

24. Maekawa, T.; Yamashita, S.; Nagao, S.; Hayashi, N.; Ohashi, Y.; on behalf of the Brain-Hypothermia (B-HYPO) Study Group. Prolonged Mild Therapeutic Hypothermia versus Fever Control with Tight Hemodynamic Monitoring and Slow Rewarming in Patients with Severe Traumatic Brain Injury: A Randomized Controlled Trial. J. Neurotrauma 2015, 32, 422-429. [CrossRef] [PubMed]

25. Shokouhi, G.; Haghjoo, A.G.; Sattarnezhad, N.; Asghari, M.; Sattarnezhad, A.; Asghari, A.; Pezeshki, A. Effects of Citicoline on Level of Consciousness, Serum Level of Fetuin-A and Matrix Gla- Protein (MGP) in Trauma Patients with Diffuse Axonal Injury (DAI) and GCS $\leq$ 8. Turk. J. Trauma Emerg. Surg. 2014, 20, 410-416. [CrossRef] [PubMed]

26. Skolnick, B.E.; Maas, A.I.R.; Narayan, R.K.; Van Der Hoop, R.G.; MacAllister, T.; Ward, J.D.; Nelson, N.R.; Stocchetti, N. A Clinical Trial of Progesterone for Severe Traumatic Brain Injury. N. Engl. J. Med. 2014, 371, 2467-2476. [CrossRef]

27. Wright, D.W.; Yeatts, S.D.; Silbergleit, R.; Palesch, Y.Y.; Hertzberg, V.S.; Frankel, M.; Goldstein, F.C.; Caveney, A.F.; Howlett-Smith, H.; Bengelink, E.M.; et al. Very Early Administration of Progesterone for Acute Traumatic Brain Injury. N. Engl. J. Med. 2014, 371, 2457-2466. [CrossRef]

28. Xu, G.-Z.; Li, W.; Liu, K.-G.; Wu, W.; Lu, W.-C.; Zhang, J.-F.; Wang, M.-D. Early Pressure Dressing for the Prevention of Subdural Effusion Secondary to Decompressive Craniectomy in Patients With Severe Traumatic Brain Injury. J. Craniofacial Surg. 2014, 25, 1836-1839. [CrossRef] [PubMed]

29. Asehnoune, K.; Seguin, P.; Allary, J.; Feuillet, F.; Lasocki, S.; Cook, F.; Floch, H.; Chabanne, R.; Geeraerts, T.; Roger, C.; et al. Hydrocortisone and fludrocortisone for prevention of hospital-acquired pneumonia in patients with severe traumatic brain injury (Corti-TC): A double-blind, multicentre phase 3, randomised placebo-controlled trial. Lancet Respir. Med. 2014, 2, 706-716. [CrossRef]

30. Robertson, C.S.; Hannay, H.J.; Yamal, J.-M.; Gopinath, S.; Goodman, J.C.; Tilley, B.C.; Baldwin, A.; Rivera-Lara, L.; Saucedo-Crespo, H.; Ahmed, O.; et al. Effect of Erythropoietin and Transfusion Threshold on Neurological Recovery After Traumatic Brain Injury. JAMA 2014, 312, 36-47. [CrossRef]

31. Stover, J.F.; Belli, A.; Boret, H.; Bulters, D.; Sahuquillo, J.; Schmutzhard, E.; Zavala, E.; Ungerstedt, U.; Schinzel, R.; Tegtmeier, F.; et al. Nitric Oxide Synthase Inhibition with the Antipterin VAS203 Improves Outcome in Moderate and Severe Traumatic Brain Injury: A Placebo-Controlled Randomized Phase Ila Trial (NOSTRA). J. Neurotrauma 2014, 31, $1599-1606$. [CrossRef] [PubMed] 
32. Mousavi, S.N.; Samini, F.; Nematy, M.; Philippou, E.; Safarian, M.; Tavallaiee, S.; Norouzy, A. Hyperglycemia and antibody titres against heat shock protein 27 in traumatic brain injury patients on parenteral nutrition. Iran. J. Basic Med. Sci. 2014, 17, 119-122. [CrossRef] [PubMed]

33. Fard, S.A.; Habibabadi, M.R.; Moein, P.; Naderan, M.; Norouzi, R.; Aminmansour, B. The efficacy of cyclosporine-A on diffuse axonal injury after traumatic brain injury. Adv. Biomed. Res. 2014, 3, 35. [CrossRef] [PubMed]

34. Lumba-Brown, A.; Harley, J.; Lucio, S.; Vaida, F.; Hilfiker, M. Hypertonic Saline as a Therapy for Pediatric Concussive Pain. Pediatr. Emerg. Care 2014, 30, 139-145. [CrossRef] [PubMed]

35. Helmy, A.; Guilfoyle, M.R.; Carpenter, K.; Pickard, J.D.; Menon, D.K.; Hutchinson, P.J. Recombinant Human Interleukin-1 Receptor Antagonist in Severe Traumatic Brain Injury: A Phase II Randomized Control Trial. Br. J. Pharmacol. 2014, 34, 845-851. [CrossRef]

36. Jagannatha, A.T.; Sriganesh, K.; Devi, B.I.; Rao, G.S.U. An equiosmolar study on early intracranial physiology and long term outcome in severe traumatic brain injury comparing mannitol and hypertonic saline. J. Clin. Neurosci. 2015, 27, 68-73. [CrossRef] [PubMed]

37. Wang, Y.; Li, J.-P.; Song, Y.-L.; Zhao, Q.-H. Intensive insulin therapy for preventing postoperative infection in patients with traumatic brain injury. Medicine 2017, 96, e6458. [CrossRef]

38. Moghaddam, O.M.; Lahiji, M.N.; Hassani, V.; Mozari, S. Early administration of selenium in patients with acute traumatic brain injury: A randomized double-blinded controlled trial. Indian J. Crit. Care Med. 2017, 21, 75-79. [CrossRef]

39. Jokar, A.; Ahmadi, K.; Salehi, T.; Sharif-Alhoseini, M.; Rahimi-Movaghar, V. The effect of tranexamic acid in traumatic brain injury: A randomized controlled trial. Chin. J. Traumatol. 2017, 20, 49-51. [CrossRef] [PubMed]

40. Taher, A.; Pilehvari, Z.; Poorolajal, J.; Aghajanloo, M. Effects of Normobaric Hyperoxia in Traumatic Brain Injury: A Randomized Controlled Clinical Trial. Trauma Mon. 2016, 21. [CrossRef] [PubMed]

41. Tripathi, M.; Kumar, M.; Malviya, D.; Malviya, P.S.; Kumar, V.; Tyagi, A. Influence of two anesthetic techniques on blood sugar level in head injury patients: A comparative study. Anesth. Essays Res. 2016, 10, 207-211. [CrossRef]

42. Mofid, B.; Soltani, Z.; Khaksari, M.; Shahrokhi, N.; Nakhaee, N.; Karamouzian, S.; Ahmadinejad, M.; Maiel, M.; Khazaeli, P. What are the progesterone-induced changes of the outcome and the serum markers of injury, oxidant activity and inflammation in diffuse axonal injury patients? Int. Immunopharmacol. 2016, 32, 103-110. [CrossRef]

43. Nichol, A.; French, C.; Little, L.; Haddad, S.; Presneill, J.; Arabi, Y.; Bailey, M.; Cooper, D.J.; Duranteau, J.; Huet, O.; et al. Erythropoietin in traumatic brain injury (EPO-TBI): A double-blind randomised controlled trial. Lancet 2015, 386, 2499-2506. [CrossRef]

44. Beca, J.; McSharry, B.; Erickson, S.; Yung, M.; Schibler, A.; Slater, A.; Wilkins, B.; Singhal, A.; Williams, G.; Sherring, C.; et al. Hypothermia for Traumatic Brain Injury in Children-A Phase II Randomized Controlled Trial*. Crit. Care Med. 2015, 43, 1458-1466. [CrossRef] [PubMed]

45. Silva, P.E.; Marqueti, R.D.C.; Livino-De-Carvalho, K.; De Araujo, A.E.T.; Castro, J.; Da Silva, V.M.; Vieira, L.; Souza, V.C.; Dantas, L.O.; Cipriano, G., Jr.; et al. Neuromuscular electrical stimulation in critically ill traumatic brain injury patients attenuates muscle atrophy, neurophysiological disorders, and weakness: A randomized controlled trial. J. Intensiv. Care 2019, 7, 1-13. [CrossRef]

46. Babamohamadi, H.; Ansari, Z.; Nobahar, M.; Mirmohammadkhani, M. The effects of peppermint gel on prevention of pressure injury in hospitalized patients with head trauma in neurosurgical ICU: A double-blind randomized controlled trial. Complement. Ther. Med. 2019, 47, 102223. [CrossRef] [PubMed]

47. Collaborators, C.T. Effects of tranexamic acid on death, disability, vascular occlusive events and other morbidities in patients with acute traumatic brain injury (CRASH-3): A randomised, placebo-controlled trial. Lancet 2019, 394, 1713-1723. [CrossRef]

48. Zhang, L.-M.; Li, R.; Sun, W.-B.; Wang, X.-P.; Qi, M.-M.; Bai, Y.; Bai, J.; Zheng, W.-C. Low-Dose, Early Fresh Frozen Plasma Transfusion Therapy After Severe Trauma Brain Injury: A Clinical, Prospective, Randomized, Controlled Study. World Neurosurg. 2019, 132, e21-e27. [CrossRef] [PubMed]

49. Poon, W.; Matula, C.; Vos, P.E.; Muresanu, D.F.; Von Steinbüchel, N.; Von Wild, K.; Hömberg, V.; Wang, E.; Lee, T.M.C.; Strilciuc, S.; et al. Safety and efficacy of Cerebrolysin in acute brain injury and neurorecovery: CAPTAIN I-A randomized, placebo-controlled, double-blind, Asian-Pacific trial. Neurol. Sci. 2019, 41, 281-293. [CrossRef] [PubMed]

50. Gao, J.; Wei, L.; Xu, G.; Ren, C.; Zhang, Z.; Liu, Y. Effects of dexmedetomidine vs sufentanil during percutaneous tracheostomy for traumatic brain injury patients. Medicine 2019, 98, e17012. [CrossRef] [PubMed]

51. Abdoli, A.; Rahimi-Bashar, F.; Torabian, S.; Sohrabi, S.; Makarchian, H.R. Efficacy of Simultaneous Administration of Nimodipine, Progesterone, and Magnesium Sulfate in Patients with Severe Traumatic Brain Injury: A Randomized Controlled Trial. Bull. Emerg. Trauma 2019, 7, 124-129. [CrossRef] [PubMed]

52. Taheri, A.; Emami, M.; Asadipour, E.; Kasirzadeh, S.; Rouini, M.-R.; Najafi, A.; Heshmat, R.; Abdollahi, M.; Mojtahedzadeh, M. A randomized controlled trial on the efficacy, safety, and pharmacokinetics of metformin in severe traumatic brain injury. J. Neurol. 2019, 266, 1988-1997. [CrossRef]

53. Kumar, S.A.; Devi, B.I.; Reddy, M.; Shukla, D. Comparison of equiosmolar dose of hyperosmolar agents in reducing intracranial pressure-A randomized control study in pediatric traumatic brain injury. Child's Nerv. Syst. 2019, 35, 999-1005. [CrossRef]

54. Gobatto, A.L.N.; Link, M.A.; Solla, D.J.; Bassi, E.; Tierno, P.F.; Paiva, W.; Taccone, F.S.; Malbouisson, L.M. Transfusion requirements after head trauma: A randomized feasibility controlled trial. Crit. Care 2019, 23, 1-10. [CrossRef] [PubMed] 
55. Mowla, A.; Baharvahdat, H.; Ganjeifar, B.; Etemadrezaie, H.; Farajirad, M.; Zabihyan, S. Enoxaparin in the treatment of severe traumatic brain injury: A randomized clinical trial. Surg. Neurol. Int. 2019, 10, 10. [CrossRef] [PubMed]

56. Basar, S.; Younus, S.M.; Gauri, S.A.; Khan, A.A.; Imran, M.; Abubakar, S.; Sheikh, D.; Shehbaz, N.; Ashraf, J. Comparison of phenytoin versus levetiracetam in early seizure prophylaxis after traumatic brain injury, at a tertiary care hospital in Karachi, Pakistan. Asian J. Neurosurg. 2018, 13, 1096-1100. [CrossRef] [PubMed]

57. Cooper, D.J.; Nichol, A.; Bailey, M.; Bernard, S.; Cameron, P.A.; Pili-Floury, S.; Forbes, A.; Gantner, D.; Higgins, A.; Huet, O.; et al. Effect of Early Sustained Prophylactic Hypothermia on Neurologic Outcomes Among Patients with Severe Traumatic Brain Injury. JAMA 2018, 320, 2211-2220. [CrossRef] [PubMed]

58. Tomar, G.S.; Singh, G.P.; Bithal, P.; Upadhyay, A.D.; Chaturvedi, A. Comparison of Effects of Manual and Mechanical Airway Clearance Techniques on Intracranial Pressure in Patients with Severe Traumatic Brain Injury on a Ventilator: Randomized, Crossover Trial. Phys. Ther. 2019, 99, 388-395. [CrossRef] [PubMed]

59. Fakharian, E.; Abedzadeh-Kalahroudi, M.; Atoof, F. Effect of Tranexamic Acid on Prevention of Hemorrhagic Mass Growth in Patients with Traumatic Brain Injury. World Neurosurg. 2018, 109, e748-e753. [CrossRef]

60. Okonkwo, D.O.; Shutter, L.; Moore, C.; Temkin, N.R.; Puccio, A.M.; Madden, C.J.; Andaluz, N.; Chesnut, R.; Bullock, M.R.; Grant, G.A.; et al. Brain Oxygen Optimization in Severe Traumatic Brain Injury Phase-II. Crit. Care Med. 2017, 45, 1907-1914. [CrossRef] [PubMed]

61. Prasetyo, E.; Islam, A.A.; Hatta, M.; Widodo, D.; Pattelongi, I. The Profile of MMP-9, MMP-9 mRNA Expression, -1562 C/T Polymorphism and Outcome in High-risk Traumatic Brain Injury: The Effect of Therapeutic Mild Hypothermia. Neurol. Med.-Chir. 2017, 57, 612-619. [CrossRef] [PubMed]

62. Mokhtari, M.; Nayeb-Aghaei, H.; Kouchek, M.; Miri, M.M.; Goharani, R.; Amoozandeh, A.; Salamat, S.A.; Sistanizad, M. Effect of Memantine on Serum Levels of Neuron-Specific Enolase and on the Glasgow Coma Scale in Patients with Moderate Traumatic Brain Injury. J. Clin. Pharmacol. 2017, 58, 42-47. [CrossRef] [PubMed]

63. Farzanegan, G.R.; Derakhshan, N.; Khalili, H.; Ghaffarpasand, F.; Paydar, S. Effects of atorvastatin on brain contusion volume and functional outcome of patients with moderate and severe traumatic brain injury; a randomized double-blind placebo-controlled clinical trial. J. Clin. Neurosci. 2017, 44, 143-147. [CrossRef] [PubMed]

64. Rai, V.R.H.; Phang, L.F.; Sia, S.F.; Amir, A.; Veerakumaran, J.S.; Kassim, M.K.A.; Othman, J.M.I.; Tah, P.C.; Loh, P.S.; Jailani, M.I.O.; et al. Effects of immunonutrition on biomarkers in traumatic brain injury patients in Malaysia: A prospective randomized controlled trial. BMC Anesthesiol. 2017, 17, 81. [CrossRef] [PubMed]

65. Salmani, F.; Mohammadi, E.; Rezvani, M.; Kazemnezhad, A. The effects of family-centered affective stimulation on brain-injured comatose patients' level of consciousness: A randomized controlled trial. Int. J. Nurs. Stud. 2017, 74, 44-52. [CrossRef] [PubMed]

66. Khazdouz, M.; Mazidi, M.; Ehsaei, M.-R.; Ferns, G.; Kengne, A.P.; Norouzy, A. Impact of Zinc Supplementation on the Clinical Outcomes of Patients with Severe Head Trauma: A Double-Blind Randomized Clinical Trial. J. Diet. Suppl. 2017, 15, 1-10. [CrossRef] [PubMed]

67. Feng, J.-Z.; Wang, W.-Y.; Zeng, J.; Zhou, Z.-Y.; Peng, J.; Yang, H.; Deng, P.-C.; Li, S.-J.; Lu, C.D.; Jiang, H. Optimization of brain metabolism using metabolic-targeted therapeutic hypothermia can reduce mortality from traumatic brain injury. J. Trauma Acute Care Surg. 2017, 83, 296-304. [CrossRef] [PubMed]

68. Wang, H.; Cao, H.; Zhang, X.; Ge, L.; Bie, L. The effect of hypertonic saline and mannitol on coagulation in moderate traumatic brain injury patients. Am. J. Emerg. Med. 2017, 35, 1404-1407. [CrossRef]

69. Tang, C.; Bao, Y.; Qi, M.; Zhou, L.; Liu, F.; Mao, J.; Lei, Q.; Qi, S.; Qiu, B. Mild induced hypothermia for patients with severe traumatic brain injury after decompressive craniectomy. J. Crit. Care 2017, 39, 267-270. [CrossRef] [PubMed]

70. Khalili, H.; Derakhshan, N.; Niakan, A.; Ghaffarpasand, F.; Salehi, M.; Eshraghian, H.; Shakibafard, A.; Zahabi, B. Effects of Oral Glibenclamide on Brain Contusion Volume and Functional Outcome of Patients with Moderate and Severe Traumatic Brain Injuries: A Randomized Double-Blind Placebo-Controlled Clinical Trial. World Neurosurg. 2017, 101, 130-136. [CrossRef] [PubMed]

71. Chakroun-Walha, O.; Samet, A.; Jerbi, M.; Nasri, A.; Talbi, A.; Kanoun, H.; Souissi, B.; Chtara, K.; Bouaziz, M.; Ksibi, H.; et al. Benefits of the tranexamic acid in head trauma with no extracranial bleeding: A prospective follow-up of 180 patients. Eur. J. Trauma Emerg. Surg. 2018, 45, 719-726. [CrossRef] [PubMed]

72. Ghalaenovi, H.; Fattahi, A.; Koohpayehzadeh, J.; Khodadost, M.; Fatahi, N.; Taheri, M.; Azimi, A.; Rohani, S.; Rahatlou, H. The effects of amantadine on traumatic brain injury outcome: A double-blind, randomized, controlled, clinical trial. Brain Inj. 2018, 32, 1050-1055. [CrossRef] [PubMed]

73. Singh, S.; Chouhan, R.S.; Bindra, A.; Radhakrishna, N. Comparison of effect of dexmedetomidine and lidocaine on intracranial and systemic hemodynamic response to chest physiotherapy and tracheal suctioning in patients with severe traumatic brain injury. J. Anesth. 2018, 32, 518-523. [CrossRef]

74. Kumar, N.; Singh, Y.; Yadav, G.; Mathur, S.K.; Bhadani, U.K. Role of neomycin polymyxin sulfate solution bladder wash for prevention of catheter associated urinary tract infection in traumatic brain injury patient admitted to Intensive Care Unit: A prospective randomized study. Int. J. Crit. Illn. Inj. Sci. 2018, 8, 17-21. [CrossRef] [PubMed]

75. Bai, X.-F.; Gao, Y.-K. Recombinant human erythropoietin for treating severe traumatic brain injury. Medicine 2018, 97 , e9532. [CrossRef] [PubMed] 
76. Hassan, M.H.; Hassan, W.M.N.W.; Zaini, R.H.M.; Shukeri, W.F.W.M.; Abidin, H.Z.; Eu, C.S. Balanced Fluid Versus Saline-Based Fluid in Post-operative Severe Traumatic Brain Injury Patients: Acid-Base and Electrolytes Assessment. Malays. J. Med. Sci. 2017, 24, 83-93. [CrossRef]

77. Hassan, W.M.N.W.; Nasir, Y.M.; Zaini, R.H.M.; Shukeri, W.F.W.M. Target-controlled Infusion Propofol Versus Sevoflurane Anaesthesia for Emergency Traumatic Brain Surgery: Comparison of the Outcomes. Malays. J. Med. Sci. 2017, 24, 73-82. [CrossRef] [PubMed]

78. Plummer, M.P.; Notkina, N.; Timofeev, I.; Hutchinson, P.J.; Finnis, M.E.; Gupta, A.K. Cerebral metabolic effects of strict versus conventional glycaemic targets following severe traumatic brain injury. Crit. Care 2018, 22, 16. [CrossRef]

79. Kumar, N.; Khan, A.A.; Singh, Y.; Singh, A.K.; Mathur, S.K. To compare the effect of two different doses of dexmedetomidine on the attenuation of airway and pressor response during tracheostomy tube change in traumatic brain injury patients. Anesth. Essays Res. 2017, 11, 964-968. [CrossRef]

80. Vieira, E.; Guimarães, T.C.; Faquini, I.; Silva, J.L.; Saboia, T.; Andrade, R.V.C.L.; Gemir, T.L.; Neri, V.C.; Almeida, N.S.; AzevedoFilho, H.R.C. Randomized controlled study comparing 2 surgical techniques for decompressive craniectomy: With watertight duraplasty and without watertight duraplasty. J. Neurosurg. 2018, 129, 1017-1023. [CrossRef] [PubMed]

81. Schroeppel, T.J.; Sharpe, J.P.; Shahan, C.P.; Clement, L.P.; Magnotti, L.J.; Lee, M.; Muhlbauer, M.; Weinberg, J.A.; Tolley, E.A.; Croce, M.A.; et al. Beta-adrenergic blockade for attenuation of catecholamine surge after traumatic brain injury: A randomized pilot trial. Trauma Surg. Acute Care Open 2019, 4, e000307. [CrossRef] [PubMed]

82. Andrews, P.J.; Sinclair, H.L.; Rodríguez, A.; Harris, B.; Rhodes, J.; Watson, H.; Murray, G. Therapeutic hypothermia to reduce intracranial pressure after traumatic brain injury: The Eurotherm3235 RCT. Health Technol. Assess. 2018, 22, 1-134. [CrossRef] [PubMed]

83. Jauch, K.; Kowark, A.; Coburn, M.; Clusmann, H.; Höllig, A. Randomized Controlled Trials on Intracerebral Hemorrhage: A Cross Sectional Retrospective Analysis of CONSORT Item Adherence. Front. Neurol. 2019, 10. [CrossRef] [PubMed]

84. Kiehna, E.; Starke, R.M.; Pouratian, N.; Dumont, A.S. Standards for reporting randomized controlled trials in neurosurgery. J. Neurosurg. 2011, 114, 280-285. [CrossRef] [PubMed]

85. Mansouri, A.; Cooper, B.; Shin, S.M.; Kondziolka, D. Randomized controlled trials and neurosurgery: The ideal fit or should alternative methodologies be considered? J. Neurosurg. 2016, 124, 558-568. [CrossRef]

86. Horton, L.; Rhodes, J.; Wilson, L. Randomized Controlled Trials in Adult Traumatic Brain Injury: A Systematic Review on the Use and Reporting of Clinical Outcome Assessments. J. Neurotrauma 2018, 35, 2005-2014. [CrossRef]

87. Hewitt, C.; Hahn, S.; Torgerson, D.; Watson, J.; Bland, J.M. Adequacy and reporting of allocation concealment: Review of recent trials published in four general medical journals. BMJ 2005, 330, 1057-1058. [CrossRef] [PubMed]

88. Hoffmann, T.C.; Erueti, C.; Glasziou, P. Poor description of non-pharmacological interventions: Analysis of consecutive sample of randomised trials. BMJ 2013, 347, f3755. [CrossRef]

89. Ioannidis, J.P.; Caplan, A.L.; Dal-Ré, R. Outcome reporting bias in clinical trials: Why monitoring matters. BMJ 2017, 356 , j408. [CrossRef] [PubMed]

90. Simera, I.; Moher, D.; Hirst, A.; Hoey, J.; Schulz, K.F.; Altman, D.G. Transparent and accurate reporting increases reliability, utility, and impact of your research: Reporting guidelines and the EQUATOR Network. BMC Med. 2010, 8, 24. [CrossRef] [PubMed]

91. Hopewell, S.; Loudon, K.; Clarke, M.J.; Oxman, A.D.; Dickersin, K. Publication bias in clinical trials due to statistical significance or direction of trial results. Cochrane Database Syst. Rev. 2009, 2010, MR000006. [CrossRef] [PubMed]

92. Maas, A.I.; Menon, D.K.; Lingsma, H.F.; Pineda, J.A.; Sandel, M.E.; Manley, G.T. Re-Orientation of Clinical Research in Traumatic Brain Injury: Report of an International Workshop on Comparative Effectiveness Research. J. Neurotrauma 2012, $29,32-46$. [CrossRef] [PubMed]

93. Shamseer, L.; Hopewell, S.; Altman, U.G.; Moher, D.; Schulz, K.F. Update on the endorsement of CONSORT by high impact factor journals: A survey of journal "Instructions to Authors" in 2014. Trials 2016, 17, 301. [CrossRef] [PubMed]

94. Boutron, I.; Altman, D.G.; Moher, D.; Schulz, K.F.; Ravaud, P.; for the CONSORT NPT Group. CONSORT Statement for Randomized Trials of Nonpharmacologic Treatments: A 2017 Update and a CONSORT Extension for Nonpharmacologic Trial Abstracts. Ann. Intern. Med. 2017, 167, 40-47. [CrossRef] [PubMed] 